\title{
The perception of multiethnolectal Zurich German: A continuum rather than clear-cut categories
}

\author{
Marie-Anne Morand ${ }^{1}$, Sandra Schwab ${ }^{1}$, Stephan Schmid ${ }^{1}$ \\ ${ }^{1}$ Phonetics Laboratory, Department of Computational Linguistics, University of Zurich \\ marie-anne.morand@uzh.ch ORCID: https://orcid.org/0000-0002-5849-58 \\ sandra.schwab@uzh.ch ORCID: https://orcid.org/0000-0003-4485-8335 \\ stephan.schmid@uzh.ch ORCID: https://orcid.org/0000-0002-5937-5427
}

Submitted: 08/09/2020; Accepted: 10/06/2021; Published online: 15/11/2021

Citation / Cómo citar este artículo: Marie-Anne Morand, Sandra Schwab \& Stephan Schmid (2020), The perception of multiethnolectal Zurich German: A continuum rather than clear-cut categories. Loquens, 7(2), e072. https://doi. org/10.3989/loquens.2020.072

\begin{abstract}
Since about 2000, the emergence of so-called 'multiethnolects' has been observed among adolescents in German-speaking Switzerland; however, a systematic description of these varieties is lacking at present. The few existing perception studies of multiethnolects in other European countries are usually based on two or more predetermined groups that are compared. This paper investigates which labels are used for multiethnolectal Zurich German and how this way of speaking is perceived by adolescents; we adopt a perceptual sociolinguistics approach which focuses on the conceptualizations of lay people rather than on those of linguists.

In a rating experiment, 40 adolescents listened to short speech samples of 48 pupils recorded in two different schools in the city of Zurich and were asked to rate the speakers on a 7-point Likert scale according to how multiethnolectal they sounded (not at all - very strongly). The results yielded a perceptual continuum rather than a clear-cut binary categorization $[ \pm$ multiethnolectal]. A smaller follow-up experiment with 12 adult raters (using the same stimuli) yielded a highly significant correlation between the mean rating scores of the two groups of raters.
\end{abstract}

Keywords: Multiethnolects, youth language, Zurich German, sociophonetics, perception.

RESUMEN: La percepción del alemán multietnolectal de Zúrich: un continuo más que una categorización neta - A partir del año 2000 aproximadamente se ha observado la aparición de los llamados 'multietnolectos' en la Suiza de habla alemana. Sin embargo, hasta el momento no existe una descripción sistemática de estas variedades lingüísticas. Los escasos estudios de percepción que se han realizado en otros países europeos se basan por lo general en la comparación de dos o más grupos preestablecidos. Este artículo investiga qué términos se utilizan para denominar el multietnolecto hablado en Zúrich y cómo un grupo adolescentes califican esta manera de hablar, adoptando, pues, un enfoque de sociolingüística perceptiva que se centra en las representaciones de locutores comunes más que de lingüistas.

En un experimento de percepción, cuarenta adolescentes escucharon breves muestras de habla producidas por 48 escolares que habían sido grabadas en dos escuelas de la ciudad de Zúrich. La tarea de los oyentes consistió en calificar a los locutores con una escala de Likert de siete puntos según cómo de multietnolectal sonaba su habla (no en absoluto muy fuertemente). Los resultados revelan la existencia de un continuum perceptivo más que de una categorización binaria [ \pm multietnolectal].

El mismo experimento se realizó también con ocho oyentes adultos, obteniendo una correlación muy fuerte y altamente significativa con los valores de los oyentes adolescentes. Estos resultados sugieren que en la percepción del multietnolecto alemán de Zúrich no parece existir una diferencia entre una perspectiva etic y una perspectiva emic.

Palabras clave: Multietnolectos, lenguaje juvenil, dialecto alemán de Zúrich, sociofonética, percepción. 


\section{INTRODUCTION}

\subsection{Multiethnolects in Europe}

In the last decades, the emergence of so-called 'multiethnolectal' language varieties has been observed in many large European cities. In neighborhoods where the population is made up of people with various cultural backgrounds and where many different heritage languages are spoken, new speaking styles of the local varieties arose among children, adolescents and young adults. The term 'multiethnolect' was introduced by Clyne (2000, p. 87) in order to refer to a particular type of ethnolect that "several minority groups use [...] collectively". According to this concept, also "members of the dominant (ethnic) group, especially young people, [might] share it with the ethnic minorities" (ibid.). Therefore, Clyne concludes that multiethnolectal speech can be seen as "the expression of a new kind of group identity” (ibid.).

It appears that the linguistic features of multiethnolects often stem from different heritage languages (i.e., new variants for the face and price variables in London arguably emerging from Bengali; Fox, 2015, p. 228). Such innovations are assumed to be drawn from a so-called multiethnolectal 'feature pool' (Cheshire et al., 2011), which includes forms of various "languages, dialects and learner varieties" (Cheshire \& Fox, 2016, p. 288). Speakers can make use of this feature pool independently of their mother tongue(s). The features can be phonetic, lexical, or morphosyntactic, which is why multiethnolects can differ on many and sometimes all linguistic levels from the traditional way of speaking the local variety. ${ }^{1}$

Such differences obviously depend on the respective standard varieties as well as on the local varieties spoken by the autochthonous population. Apart from such language-specific differences, there seem to exist a few common cross-linguistic features, at least within the Germanic multiethnolects. In particular, a certain tendency towards a reduced syntactic complexity has been noticed in several multiethnolects (see, e.g., Siegel, 2018), as in examples (1) which illustrate the omission of directional or locative prepositions as well as of definite articles that would be required by the linguistic norms of English (1a), German (1b) and Swiss German (1c).

(1) a. I'm going countryside.

b. Geh'mer Tankstelle.

'Let's go gas station.'

c. Ich bin $H B$.

'I am main station.'

\footnotetext{
In a sense, the study of multiethnolects is located at the crossroads between variationist sociolinguistics and contact linguistics. It goes without saying, however, that this line of research focuses only on one of the many facets involved in the language repertoire and verbal behavior of multilingual migrant children, where the use of heritage languages and code switching play an important role as well (see, e.g., Krefeld, 2004; Schmid, 2020).
}

Example 1a is taken from Multicultural London English (Kerswill et al., 2007, p. 8), 1b from Türkenslang spoken in Germany (Füglein, 2000, p. 84; as cited in Auer, 2003 , p. 258), and 1c represents multiethnolectal Swiss German (Häberli \& Wollensack, 2006; as cited in Tissot et al., 2011, p. 326). At the lexical level, certain loan words from Arabic or Turkish seem to be quite frequent in several multiethnolects of Germanic languages (e.g., Dirim \& Auer, 2004; Quist, 2010). Also, with regard to prosody, it has been observed that several multiethnolects of Germanic languages make use of a (non-autochthonous) syllable-timed rhythm (Auer, 2003; Tissot et al., 2011; Torgersen \& Szakay, 2012).

As regards the linguistic features of multiethnolectal Zurich German, the examination of speech samples from various sources has led to the observation that this way of speaking differs in several respects from the traditional dialect (e.g., Schmid, 2012; Tissot et al., 2011). A systematic investigation of multiethnolectal Zurich German has started only recently, but there is now a growing body of empirical evidence for the pervasiveness of phonetic and morphosyntactic features in the speech of adolescents (mostly) with migration background (e.g., Bruno, 2019; Morand et al., 2019a).

Our current research project focuses on phonetic features, analyzing multiethnolectal speech not only in production (analyzing the acoustic correlates of phonetic features in production), but also from the point of view of its sociolinguistic perception, investigating the extent to which listeners recognize such speech as multiethnolectal. In particular, we address the issue of whether 'multiethnicity' is categorized as a dichotomy (i.e., traditional vs. multiethnolectal speech) or as a continuum (i.e., various degrees between these two end points). To this aim, we conducted a rating experiment (Exp. 2) in which participants were asked to rate speech samples on a 7-point Likert scale. To determine how to formulate the task in this experiment, a labeling experiment (Exp. 1) was conducted first.

The remainder of the paper is organized as follows. We will first present the sociolinguistic and ethnic situation in the city of Zurich where we conducted our experiments (1.2.). Second, we will mention some phonetic features of so-called 'multiethnolectal Zurich German' (1.3.) before formulating our research questions (1.4.). Third, we will report on the labeling (2.) and the rating (3.) experiments. Finally, we will discuss implications of our work for future research (4.) and end with some concluding remarks (5.).

\subsection{Sociolinguistic and ethnic situation in the city of Zurich}

In German-speaking Switzerland, the locals have two language varieties at their disposal: (Swiss) Standard German and at least one Alemannic dialect (usually referred to with the umbrella term Swiss German). In contrast to other German-speaking countries, there is, however, no standard-dialect continuum (Ammon, 2003); rather, the sociolinguistic situation has been described as 
diglossia (Ferguson, 1959; Fishman, 1967, p. 31; Rash, 1998) with rather clear-cut boundaries between the 'high' variety (Swiss Standard German) and the 'low' variety (Alemannic dialects). Therefore, immigrant children have to cope in some way with this diglossic situation, acquiring Swiss German in everyday communication and learning (Swiss) Standard German through formal instruction at school (see Schmid, 2020).

Zurich German is the Alemannic dialect spoken in the city of Zurich as well as in other municipalities of the canton of Zurich. Henceforth we will refer to the traditional way of speaking the Zurich dialect as 'traditional Zurich German', in contrast to the multiethnolectal variety of the Zurich dialect which we label as 'multiethnolectal Zurich German'.

The current research has been conducted in the city of Zurich which, by the end of 2017, had 409'241 inhabitants (Stadt Zürich, 2019). Note that more than $30 \%$ of its residents are not Swiss citizens, instead originating from 169 different countries. Thus, Zurich's population is rather multicultural as is evident by the different languages spoken at home. Table 1 represents a non-exhaustive list of the languages most frequently spoken (Riegelnig, 2012).

Given such ethnic and linguistic diversity, it is quite natural that multiethnolectal varieties of Zurich German emerge in this multilingual and multicultural setting.

\subsection{Typical features of multiethnolectal Zurich German}

Though the focus of the present study is on sociolinguistic perception, a few words on some typical linguistic features of multiethnolectal Swiss German are nevertheless in order. On the phonetic level, there are at least three segmental features and one suprasegmental characteristic that may distinguish traditional from multiethnolectal Zurich German (see Schmid, 2012).

On the segmental level, the first feature is related to the fortis/lenis distinction for plosives employed in traditional Swiss German dialects instead of the feature [ \pm voice] (see Fleischer \& Schmid, 2006, p. 244-246). There is evidence

Table 1: Languages most frequently spoken at home by the permanent resident population of Zurich (Riegelnig, 2012; multiple answers possible).

\begin{tabular}{lc}
\hline Language & Percentage \\
\hline Swiss German & $69.3 \%$ \\
Standard German & $22.7 \%$ \\
English & $8.8 \%$ \\
Italian & $7.1 \%$ \\
French & $4.5 \%$ \\
Serbian/Croatian & $4.1 \%$ \\
Spanish & $3.1 \%$ \\
Portuguese & $3.1 \%$ \\
Albanian & $2.3 \%$ \\
\hline
\end{tabular}

that multiethnolectal Zurich German uses voicing instead of the traditionally voiceless lenis plosives $/ \mathrm{b}$ d $\mathrm{g} g /$ (Morand et al., 2019a). The second segmental feature regards a phonotactic constraint for traditional Swiss German dialects, according to which word-initially only lenis fricatives are allowed (Dieth, 1950, p. 360). There is reason to believe that this phonotactic constraint is abandoned in multiethnolectal Zurich German in which word-initial fricatives are realized with a longer duration (Morand et al., 2019b). As a third segmental feature, the labiodental approxi mants of traditional Zurich German are supposed to be realized in a more fricative-like manner (i.e., with a longer duration) in multiethnolectal Zurich German.

These phonetic features of multiethnolectal Zurich German on the segmental level can be illustrated by means of three sentences which were read aloud by the informants of our research project. The transcriptions in (2) display the voicing of traditionally voiceless lenis plosives (2a), the occurrence of a fortis fricative in word-initial position (2b), and fricative-like realization of a word-initial labiodental approximant (2c). Zurich German spelling is based on Dieth orthography (Dieth, 1938/1986).

(2) a. Das isch en hèrte ['bodə]

'That's a hard floor.'

b. Ich gsee de [fuxs]

'I see the fox.'

c. Mir sueched e ['v:onig]

'We are looking for an apartment.'

Traditional Zurich German equivalents are illustrated by means of the phonetic transcriptions in (3), which contain voiceless lenis plosives (3a), a lenis fricative in word-initial position (3b), and a word-initial labiodental approximant (3c).

(3) a. Das isch en hèrte ['bodəo]

b. Ich gsee de [vuxs]

c. Mir sueched e ['vonig]

On the suprasegmental level, multiethnolectal Zurich German is believed to use less vowel reduction in unstressed syllables as well as to shorten stressed long vowels which leads to the impression of a more syllabletimed rhythm of this variety (Tissot et al., 2011, p. 327).

On the morphosyntactic level, a recent analysis of data gathered within the current research project found that function words - such as directional and locative prepositions as well as definite and indefinite articles are occasionally omitted (Bruno, 2019). Finally, on the lexical level, a certain mixture between the standard and the dialectal variety can be observed in multiethnolectal Zurich German (Morand et al., accepted; Schmid, 2020).

How the pronunciation and lexical choices of adolescent speech are perceived and socially interpreted is one of the issues investigated in our research project. In the present study, instead, we do not focus on the production of specific linguistic features (see, however, Morand et 
al., 2019b; Morand et al., 2020; Morand et al., accepted); rather, our aim is to discuss general methodological aspects involved in research on sociolinguistic perception, such as the labels to be used in rating experiments on speech styles and the discrete or continuous nature of cognitive representations related to multiethnolectal speech.

\subsection{Research questions}

From the point of view of speech production and verbal interactions there is no doubt that multiethnolects constitute a sociolinguistic reality in several European countries (Auer \& Røyneland, 2020; Nortier \& Svendsen, 2015; Quist \& Svendsen, 2010) and in German-speaking Switzerland as well. Nevertheless, it is not as clear how multiethnolectal speech is perceived by listeners. We have therefore formulated the following four research questions:

- RQ1: Which terms are used by 'outsiders' (adults) to refer to multiethnolectal speech?

- RQ2: How is multiethnolectal speech perceived by 'insiders' (adolescents)? Is there a categorical perception of multiethnolectal Zurich German or is the perception rather a matter of degree?

- RQ3: To what extent is the adolescents' perception of multiethnolectal speech influenced by the following factors? (i) Mono-/bilingualism of speakers, (ii) neighborhood/school of speakers and (iii) mono-/ bilingualism of raters.

- RQ4: How is multiethnolectal speech perceived by 'outsiders' (adults)? To what extent does the perception of multiethnolectal speech by 'outsiders' differ from the perception of 'insiders'?

The first research question (RQ1) will be addressed in the labeling experiment (Exp. 1), whereas the second research question (RQ2) guides the rating experiment (Exp. 2). In the analysis of the results of the rating experiment, additional factors are also taken into account in order to investigate their influence on the perception of multiethnolectal speech (RQ3). To answer the last research question (RQ4), the results of the rating experiment with the adolescents are compared with the rating of adult raters.

\section{EXPERIMENT 1: LABELING MULTIETHNOLECTAL ZURICH GERMAN}

According to a dichotomy introduced by Pike (1967, p. 37), one may adopt two different perspectives to the study of language and human behavior for which he coined the labels 'etic' and 'emic'. The etic standpoint "studies behavior as from outside of a particular system, and as an essential initial approach to an alien system" (ibid.). Emic refers to a standpoint "from inside the system" (ibid.). Thus, in our research questions 'outsiders' refer to the etic perspective and 'insiders' to the emic perspective. The two approaches put forward by Pike in the late 1960 s are to be seen as complementary, according to Berry (1999) and are still widely used (Gorlée \& Anderson, 2011).

Given these two viewpoints, there may well be different labels associated with multiethnolectal speech. We expect that in the rating experiment the adolescent raters take an 'emic' viewpoint (as we assume multiethnolectal speech to be closely linked to youth language), whereas adults are supposed to adopt an 'etic' perspective.

\subsection{Labels for multiethnolects: the etic perspective}

A preliminary problem related to the categorization of multiethnolectal speakers regards the different labels that have been used in order to refer to the way they speak. The labels given to the various multiethnolects (see Nortier \& Dorleijn, 2013) are mostly 'etic' terms (Pike, 1967) coined and used by researchers and/or the adult population; but they are hardly used by the adolescents. Such labels include Kebab-norsk in Oslo (Opsahl \& Røyneland, 2016), Rinkeby Svenska in Stockholm (Kotsinas, 1988), Straattaal in Amsterdam (Appel, 1999), Citétaal in Genk (Marzo \& Ceuleers, 2011), Kiezdeutsch in Berlin (Wiese, 2006), and Türkendeutsch in other regions of Germany (Androutsopoulos, 2001; Auer, 2003).

As regards the names coined for Swiss German multiethnolects, it appears that the most widespread labels used in the public media and also quoted in the scientific literature have been Jugodeutsch (or its Swiss German equivalent Jugotü̈tsch) as well as Balkandeutsch or Balkanslang (Schmid, 2017, p. 109; Tissot et al., 2011, p. 321). In the public media and in blogs, we find the glottonym Ausländerdeutsch ('German of foreigners'; Man in Helvetica, 2010; as cited in Montefiori, 2017, pp. 37-38), sometimes also accompanied by the adjective gebrochenes 'broken' (Huber, 2000). The labels Jugodeutsch, Balkandeutsch and Ausländerdeutsch are compounds denoting varieties of the German language used by particular groups of speakers. The noun Jugo is a short form, derived by clipping from the noun or adjective Jugoslawe/Jugoslawisch 'Yugoslavian' (lit. 'southern Slav') ${ }^{2}$ in certain contexts, it may assume a negative connotation. According to the data published by Riegelnig (2012), Serbian and Croatian are the languages spoken at home the most in Zurich after English and the Swiss national languages German, French, and Italian (see Table 1, above), which is probably due to the arrival of Yugoslavian refugees in the 1990s.

The term Jugodeutsch was and is still widely used, but lately it has been partially replaced in public discourse by

\footnotetext{
${ }^{2}$ The term thus refers to people originating from the former Socialist Federal Republic of Yugoslavia (1963-1992), which then was split into a number of different countries, namely (in alphabetical order) Bosnia and Herzegovina, Croatia, Kosovo, North Macedonia, Montenegro, Serbia, and Slovenia (Hayden, 2013). In the early 1990s, the outbreak of the Yugoslav wars led to the arrival of many refugees in Switzerland.
} 
the label Balkanslang, ${ }^{3}$ which also appears to be negatively connotated (Schmutz, 2013).

Both Jugodeutsch and Balkanslang denote stereotypical speakers of multiethnolectal Zurich German, although its speakers are not exclusively from the regions suggested by these terms. Instead, the more general (and maybe less negatively connotated) term Ausländerdeutsch simply highlights the fact that most speakers of multiethnolectal Zurich German have either migrated to Switzerland themselves or their parents or grandparents have. However, it might also be the case that some speakers of multiethnolectal Zurich German do not have a foreign background (similar to the 'de-ethnicization' of multiethnolects observed in Germany by Auer, 2003).

\subsection{Labels for multiethnolects: the emic perspective}

At this point it is interesting to note that the label Ausländerdeutsch also emerges as an emic label in the data collected within our research project. In fact, this term is used by some adolescents to differentiate their speech deliberately from traditional Swiss German dialects, as is shown by the following extract from a group interview recorded for our project:

(4) Jugendspraach isch so Schwizertüütsch, aber nöd soo normals Schwizertüütsch, sondern so wie miir redet, säge mer so Usländertüütsch.

'Youth language is like Swiss German, but not like normal Swiss German, more like how we talk, let's say foreigner German.'

Adolescents interviewed in our research project also used the term Ghettospraach ('ghetto language'), and sometimes they claim to make use of Straassewörter ('street words'). In general, these interviews revealed that the adolescents seemed to focus mainly on the lexical level when describing or labeling multiethnolectal Zurich German.

\subsection{Method}

As has been shown above, there are many possible labels one could have used for our experiment on the rating of multiethnolectal Zurich German. Therefore, in order to determine the best way to formulate the question to be asked for rating the speech samples, we decided to conduct a labeling experiment in which we tried to find the most suitable, i.e., unambiguous and not negatively connotated term for multiethnolectal Zurich German.

This experiment was run online by means of the Labguistic platform (www.labguistic.com). One hundred and one native speakers of Swiss German or

\footnotetext{
${ }^{3}$ The geographical denomination Balkan (which in Ottoman Turkish means 'chain of wooded mountains') is often used synonymously with Southeast Europe. In everyday language, the term mostly refers to the above-mentioned parts of former Yugoslavia, though the geographical denomination would also include Albania, Bulgaria, Greece, and Romania (Chiari \& Groß, 2009).
}

German participated in the experiment, their age ranging from 15 to 55 at the time of recording (mean age $=25.0$ ). The listeners heard a stereotypical speech sample of a young male speaker of multiethnolectal Zurich German. The speech sample had been recorded during a television talk show (see also Schmid, 2017, 2020). In the online test, participants were asked to answer the following question:

(5) Wie sagst Du dieser Art zu sprechen? Bitte schreib hier Deine Antwort(en).

'How do you call this way of speaking? Please write down your answer(s).'

The participants could write down multiple answers in a white empty box. Space was not limited.

\subsection{Results and discussion}

The answers have been grouped into 13 categories, e.g., Albanian, youth slang, or subjective descriptions (under this heading we classified adjectives such as "unpleasant" or "unappealing"). The five categories with the most answers in descending order are Jugodeutsch (26\%), Ausländerdeutsch (17\%), subjective descriptions (13\%), Slang (9\%), and Balkanslang (9\%).

Other responses indicated sociolinguistic terms (such as ethnolect or sociolect) or very specific labels regarding either the assumed migration background (such as Albaner 'Albanian') or the neighborhood this person might have grown up in (such as Dietiker 'inhabitant of Dietikon', which is a very multicultural municipality and part of the agglomeration of the city of Zurich).

In order to determine the most suitable term for the rating experiment, we did not consider the use of sociolinguistic terms, as they probably would not have been understood by the adolescents. We also discarded the category of subjective descriptions for a possible denomination of multiethnolectal Zurich German, because many of the terms mentioned therein are not only highly anecdotal and therefore difficult to interpret, but some of them might even be offensive. For a similar reason, we excluded the category Jugodeutsch, considering that it still appears to be rather negatively connotated at least to some people. ${ }^{4}$

Eventually, we opted for the term slang which appeared to be the most neutral one, adding Ausländerdeutsch in brackets and quotation marks (due to its potentially negative connotation).

\footnotetext{
${ }^{4}$ It is true that derogatory terms created by outsiders are sometimes used by members of the minority groups as well (see the term Kanak Sprak for multiethnolects in Germany). In Switzerland, such "appropriated uses [...] for non-derogatory purposes" (Bianchi, 2014) might be observed with regard to the term Balkan, which is often associated with drugs, criminal behavior etc. (see Woker, 2008).

Nevertheless, it would be inappropriate to propose such terms in a multiethnic school for an experiment conducted by researchers of Swiss nationality. As a matter of fact, the Ethics Committee of our University explicitly invited us to refrain from the use of the term Balkanslang.
} 


\section{EXPERIMENT 2: RATING MULTIETHNOLECTAL ZURICH GERMAN}

The first perception experiment to categorize multiethnolects we are aware of is Bodén's (2010) study conducted in Sweden, which assumes a simple dichotomy opposing one category 'multiethnolect' to another category 'not multiethnolect' (p. 67). In the experiment, however, listeners were not directly asked whether the speakers spoke multiethnolect or not; rather, colloquial labels derived from the names of particular neighborhoods such as Rosengård Swedish (Malmö), Gårdstenish (Gothenburg), and Rinkeby Swedish (Stockholm) were used.

With a somewhat different approach, a gradient categorization of multiethnolectal speech was achieved by Grondelaers and van Gent (2019) in a preliminary experiment for their study on the evaluation of 'Moroccanflavored Netherlandic Dutch'. In this experiment, students were asked to determine accent strength on a 7-point scale of different speakers with a Moroccan background, who were afterwards grouped into speakers of mildly and strongly accented Moroccan-Dutch.

Most studies on multiethnolects, however, base their categories for further investigations not on the perception of these ways of speaking, but rather on the social characteristics of their speakers (nationality, ethnicity, neighborhood, etc.). For example, in Kern and Selting's (2011) edited volume Ethnic styles of speaking in European metropolitan areas, several distinctions between groups of speakers can be found in different European countries including Germany, France, Great Britain, Finland, and the Netherlands. These distinctions vary between two, three, or four groups of speakers. For instance, in a study on the Berlin multiethnolect, Freywald et al. (2011) investigated adolescent participants from two schools - one located in a 'multiethnic' neighborhood and the other located in a 'monoethnic' neighborhood - and thus compared two groups of speakers with regard to the recognition and acceptability of their way of speaking. As regards multiethnolectal French, Fagyal and Stewart (2011) compared prosodic style-shifting of three speakers possibly belonging to two groups (bilingual and monolingual): two bilingual speakers with either Algerian or equatorial African descent, and one monolingual speaker without recent immigrant origins. For Great Britain, Fox et al. (2011) report on a number of studies which differentiate between two or three groups: (1) White British, Bangladeshi, and Mixed Race; (2) Anglo and non-Anglo; or (3) Pakistani, Black Caribbean and White English. For Finland, Lehtonen (2011) operated a three-way distinction between local spoken Finnish, (written) Standard Finnish and so-called 'Bad Finnish'. Finally, Hinskens (2011) investigated four different groups of speakers in two Dutch cities: Moroccan, Turkish, 'white' Dutch with strong inter-ethnic ties, and 'white' Dutch with weak inter-ethnic ties.

Summing up, we find at least three reoccurring themes in the speaker group categorizations operated by these linguists: ethnicity as in Fox et al. (2011) or Hinskens (2011), language background as in Fagyal and Stewart (2011), or multiculturalism of neighborhood as in Freywald et al. (2011). These clear-cut distinctions may ease comparisons, as the data can be ordered in terms of groups, but it might also be the case that a continuum represents the perception of multiethnolectal ways of speaking more accurately. Such a continuum is supposed to be based on small differences between speakers in their use or the strength of certain features, which are arguably also perceived by listeners.

\subsection{Method}

\subsubsection{Participants}

Three groups of participants were involved in the rating experiment: (i) the adolescents that the speech samples are taken from (speakers), (ii) the adolescents that rated the speech samples (adolescent raters), and (iii) the adults that rated the speech samples (adult raters).

Speakers. The stimuli of this experiment were speech samples recorded from 48 Zurich German speaking adolescents. The speakers were ranging in age from 13 to 16 at the time of recording (mean age $=14.3$ ); twenty-eight of them are female. Eighteen of the analyzed speakers were pupils from a school which is located in a very multicultural neighborhood (speakers whose code in Figure 1 starts with $B u$ ), whereas 30 pupils went to a school which is located in a somewhat less multicultural neighborhood (speakers whose code in Figure 1 starts with $L e$ ).

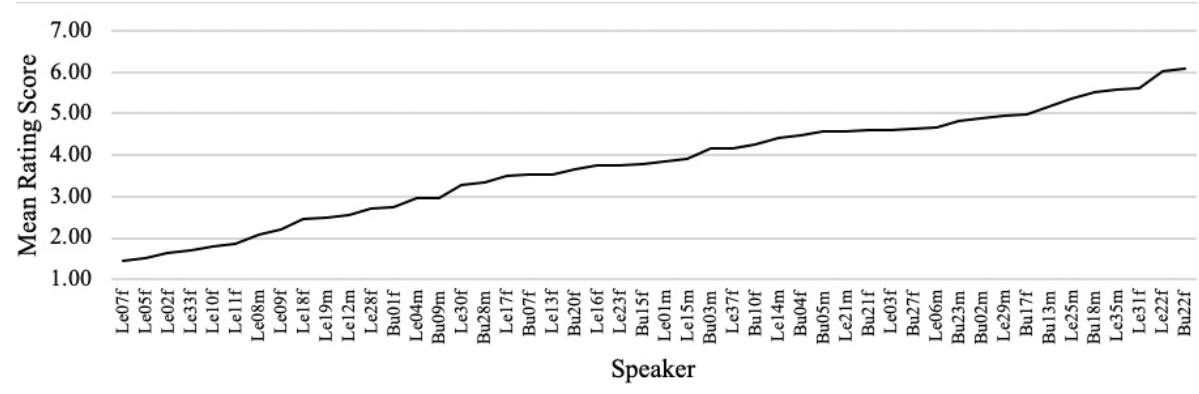

Figure 1: Mean rating score for the adolescent raters as a function of speakers. 
More than $60 \%$ of the speakers $(n=29)$ are Swiss citizens (sometimes in addition to other nationalities); this percentage is slightly lower than in the city of Zurich (68\%). In the very multicultural neighborhood (Seebach; school $B u$ ), 61\% are Swiss citizens, whereas in the less multicultural neighborhood (Albisrieden; school Le), $73 \%$ of the overall population does have the Swiss nationality (own calculations based on Stadt Zürich, 2018).

Only seven speakers have no siblings; those who do have at least one sibling indicate that they (also) talk Zurich German with each other. This seems especially relevant for those adolescents who declared to speak other/additional languages at home. Nevertheless, Zurich German is part of the primary socialization of these speakers as well, even if their language socialization may differ from those adolescents who grew up monolingually with Zurich German.

The adolescents indicated in a questionnaire which languages they spoke before kindergarten. In both schools, Swiss German is by far the language which was indicated most often. However, in the school located in the very multicultural neighborhood, only $29 \%$ of the pupils specified that they spoke Swiss German before kindergarten. In contrast, in the school located in the less multicultural neighborhood, the corresponding percentage was slightly higher, as $39 \%$ of the pupils specified that they spoke Swiss German before kindergarten.

In total, only nine adolescents grew up monolingually with Zurich German, whereas 39 adolescents grew up in a bi- or multilingual environment. Speakers were coded as being bi- or multilingual if they have indicated in the questionnaire, they spoke other languages besides Swiss/ Zurich German before kindergarten. Standard German ('Hochdeutsch') was also considered 'another language' although its foreign language status is debatable (Hägi \& Scharloth, 2005).

The most frequent other languages indicated by the adolescents were Albanian $(\mathrm{n}=8)$, Standard German $(\mathrm{n}=7)$, Spanish $(\mathrm{n}=4)$, Arabic $(\mathrm{n}=3)$, and Portuguese $(n=3)$ in descending order. Further languages include (but are not limited to) European languages such as Croatian $(\mathrm{n}=3)$, English $(\mathrm{n}=2)$, French $(\mathrm{n}=2)$, Italian $(\mathrm{n}=2)$, and Turkish $(\mathrm{n}=2)$, but also non-European languages such as Punjabi $(\mathrm{n}=1)$, Somalian $(\mathrm{n}=1)$, Thai $(\mathrm{n}=1)$, Twi $(\mathrm{n}=1)$, and Urdu $(\mathrm{n}=1)$ (in alphabetic order). Additionally, all pupils also learned English and/ or French in a school setting.

Adolescent raters. The experiment was conducted in a different school to make sure that the raters did not recognize the voice of any speakers. However, they were specifically chosen to resemble the speakers on as many levels as possible (i.e., age, social structure of the neighborhood and - to some extent - also the heterogeneity of mother tongues) in order to obtain an emic rating of the speech samples.

Forty pupils in a third school in the city of Zurich participated in the rating experiment. This school is located in a neighborhood (Alt-Wiedikon) in which $66 \%$ of the population are Swiss citizens (own calculations based on Stadt Zürich, 2018). The adolescents in this group ranged in age from 14 to 16 at the time of the experiment (mean age $=14.8$ ); twenty-five of them are female. More than half of them $(n=21)$ indicated that they are Swiss German monolinguals, the others stated that they are bilinguals $(n=19)$. The adolescent raters' (additional) mother tongues include (but are not limited to) Tamil $(\mathrm{n}=3)$, Turkish $(\mathrm{n}=3)$, English $(\mathrm{n}=2)$, Kurdish $(\mathrm{n}=2)$, Italian $(\mathrm{n}=2)$, and Spanish $(n=2)$ (in descending order). According to the percentage of Swiss citizenship which was used as a proxy for multiculturalism, this neighborhood should fall in between the two neighborhoods of the speakers. However, the percentage of adolescents that grew up monolingually appears to be higher than in the less multicultural school.

Adult raters. Twelve adults at the university of Zurich also participated in the rating experiment. These adults are considerably older than the speakers and the adolescent raters described above (mean age $=33.7$; ranging from 18 to 67 at the time of recording); seven of them are female. Seven are Swiss German monolinguals and four are bilinguals. The adult raters' (additional) mother tongues are English $(\mathrm{n}=1)$, Italian $(\mathrm{n}=1)$, Portuguese $(\mathrm{n}=1)$, and Serbian $(\mathrm{n}=1)$ (in alphabetical order). For practical reasons, adult raters were recruited in linguistic courses at the University of Zurich.

Summarizing the information on the two different groups of raters, Table 2 shows mean age, age range, gender distribution, and bilingualism of the adolescent and adult raters in this experiment.

\subsubsection{Material}

At the beginning of the data collection for the research project, individual interviews had been conducted with the speakers. Towards the end of these interviews, participants were asked to describe a picture, which was taken from the Boston Diagnostic Aphasia Examination (Goodglass \& Kaplan, 1983).

For the stimuli to be used for the rating experiment, we chose a speech sample between 5 to 7 seconds in the middle of the picture description. In (6), three examples of the stimuli are given; the Zurich German spelling is based on Dieth orthography (Dieth, 1938/1986):

Table 2: Summary of information on adolescent and adult raters.

\begin{tabular}{lll}
\hline & Adolescents & Adults \\
\hline Number of raters & 40 & 12 \\
Mean age & 14.8 & 33.7 \\
Age range & $14-16$ & $18-67$ \\
Gender & 25 female & 7 female \\
distribution & 15 male & 5 male \\
Languages & 21 bilinguals $(52.5 \%)$ & 4 bilinguals \\
& & $(33.3 \%)$ \\
\hline
\end{tabular}


(6) a. De Bueb git ire de Keks und

Wasser isch am abelaufe.

'The boy gives her the cookie and water is running down.'

b. D Muetter, käi Anig, gseet irgendwie so chli gnèrvt us.

'The mother, no idea, looks somehow a little bit annoyed.'

c. Isch äifach we me nöd uufpasst bi bäidne Situazione. Daa passt me nöd uuf dass das Wasser überlauft und dötte passt me nöd uuf dass er vom Stuel gheit.

'It's just when you don't pay attention in both situations. Here one doesn't pay attention that the water is overflowing and there one doesn't pay attention that he's falling off the chair.'

\subsubsection{Procedure}

The rating experiment was run online with the Labguistic platform (www.labguistic.com). Raters were asked to answer the following question based on the results of the labeling experiment (see Exp. 1):

\section{(5) Inwieweit denkst Du, dass die Person}

Slang ("Ausländerdeutsch") spricht?

'To what extent do you think the person speaks slang (“German of foreigners”)?'

Participants were instructed to answer on a 7-point Likert scale ranging from 1 (not at all) to 7 (very strongly). Speech samples could only be listened to twice and no decision could be entered before the audio file was finished playing, in order to make sure that the raters did not simply click through the experiment as quickly as possible. The stimuli were presented in random order.

The online experiment was conducted in the school's computer room (adolescent raters) or on a personal computer (adult raters). Our team members guided the adolescent raters through the first part of the experiment (introduction, short questionnaire, training with four additional speech samples of speakers not included in the analysis). During the instructions, they were told that a certain way of speaking among youth is oftentimes called "slang" by teachers and parents. We ensured that the pupils knew what was meant by that. All listeners performed the experiment individually with headphones and self-paced. The rating experiment with the adolescent raters lasted about 15 minutes.

\subsection{Results}

In the following, the results of the adolescent raters will be presented first and later compared to the results of the adult raters.

\subsubsection{Adolescent raters}

Figure 1 shows the mean rating score for the adolescent raters as a function of the speakers. The rating scores correspond to mean values (calculated from the forty adolescent raters) for every speech sample; these mean values vary between 1.45 and 6.01 on the 7-point Likert scale. On average, the speakers were given a 3.78 rating score (with a standard deviation of 1.26).

Speakers are sorted by their respective mean values. These mean rating scores yield a clear continuum ranging from those speech samples that were rated as "not at all slang ('Ausländerdeutsch')" towards those speech samples that were perceived "very strongly as slang ("Ausländerdeutsch')". It is reasonable to assume that adolescents located near the left spoke so-called 'traditional Zurich German'; instead, the adolescents located near the right may be considered speakers of 'multiethnolectal Zurich German'. It is of paramount importance to highlight the fact that it is impossible to define two or more clear-cut categories in this figure, as the scores gradually move from the left end of the continuum to the right end. Hence, on the basis of this rating experiment no dichotomous opposition between traditional and multiethnolectal Zurich German is recognizable.

As regards the individual factors of the adolescent raters which might have influenced their answers, the responses were checked for possible effects of the raters' and the speakers' mono-/bilingualism or the neighborhood/ school the speakers are from. In general, it was assumed that monolingual speakers and speakers going to school in the less multicultural neighborhood would be rated as speaking less multiethnolectal Zurich German. Furthermore, one might expect that bilingual raters perceive the speech samples in total as being less multiethnolectal. Two groups were compared within raters and speakers: monolingual vs. bi-/multilingual adolescents on the one hand and the two neighborhoods/schools of the speakers on the other hand.

Regarding the linguistic repertoire of the adolescent raters, the sample consists of 21 monolingual Swiss German speakers and 19 bilingual speakers. A t-test yielded no significant effect of the raters' mono- or bilingualism on their mean rating of the speech samples (monolingual $=3.73 ;$ bilingual $=3.83 ; t(38)=-0.49$, $p=.630$ ). For the speakers, there are only nine monolingual Swiss German speakers and 39 bi- or multilingual speakers among the adolescents recorded. In this case, we did find a significant effect of the speakers' linguistic repertoire (monolingual vs. bi- or multilingual) on the raters' categorizations $(t(46)=2.27, p=.028)$. As was to be expected, the monolingual Swiss German speakers were rated as speaking less multiethnolectal Zurich German (mean $=2.94)$ as the bi- and multilingual speakers (mean $=3.97)$. It is noteworthy, however, that those rated the lowest (mean rating $<2.00$ ) were all bilingual speakers with Standard German, Thai, and Italian acquired before kindergarten, which relativizes the general tendency to some extent. 
As regards the comparison of the scores attributed to the pupils according to which of the two different schools they attended, we found a significant effect on the rating scores $(t(46)=2.82, p=.007)$. Indeed, speakers from the school in the very multicultural neighborhood were rated significantly higher on average (mean $=4.35$ ) than the speakers from the school located in the less multicultural neighborhood (mean $=3.43$ ). On the basis of our knowledge, it is not clear whether this is simply a consequence of the higher proportion of monolingual speakers in the less multicultural neighborhood ( 8 out of 9 monolingual speakers were recorded in this school), or if the school itself as a 'community of practice' (Eckert \& McConnellGinet, 1992) has an impact on the adolescents' ways of speaking, regardless of their language biography.

\subsubsection{Adult raters}

We assume that the adolescents who rated the speech samples produced by peers from another school adopt an emic perspective, as they share a similar generational background with the speakers. Instead, adult listeners might perceive the speech samples differently, from an etic perspective, as they belong to different communities of linguistic practice. Therefore, in order to test to which extent emic and etic ratings differ, a number of adults were asked to rate the same speech samples.

The results of this comparison are depicted in Figure 2, which plots the mean scores given by the adolescent raters on the $y$-axis against the means scores given by the adult raters on the $\mathrm{x}$-axis. As is illustrated by the slope of the regression line in Figure 2, we observe as a general tendency a strong and highly significant positive correlation

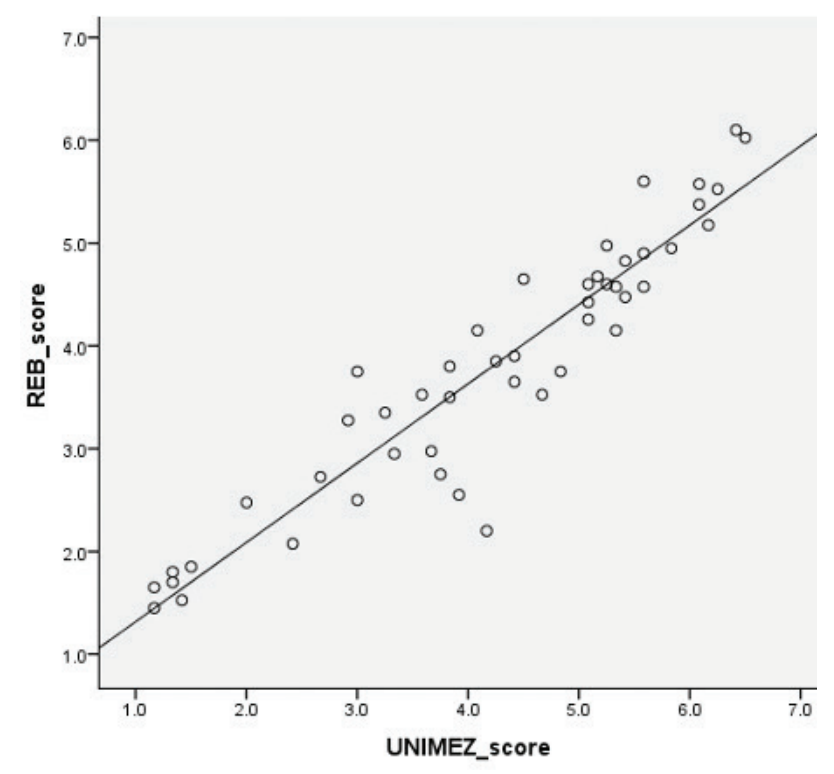

Figure 2: Mean rating scores of adolescents (y-axis) as a function of mean rating scores of adults ( $\mathrm{x}$-axis). between the ratings given by the adolescent raters and those given by the adult raters (Pearson $\mathrm{r}=.94, p<.001$ ).

We interpret this finding in the sense that, within the general Swiss German speaking community, people are able to build cognitive representations about the social characteristics of certain speakers. Moreover, it appears that even short speech samples produced by unknown voices are sufficient to activate such social representations. The strong correlation between the ratings of the two groups of listeners does indeed point to some degree of awareness about multiethnolectal Zurich German, a way of speaking which is recognizable both by 'insiders' and by 'outsiders' - hence, the strong coincidence between the emic and the etic perspective.

There are some minor differences, though. On average, the speakers were given a 4.19 rating score by the adult raters (with a standard deviation of 1.55), which is slightly higher than the mean rating of 3.78 of the adolescent raters; thus, the adults rated the whole sample on average as more multiethnolectal. Their mean values vary between 1.17 and 6.50 on a 7-point Likert scale. Indeed, a paired t-test reveals that the scores are significantly lower in the adolescents' rating than in the adults' rating $(t(47)=5.01, p<.001)$.

One could interpret this generational difference between the two groups of raters in the sense that the threshold for categorizing a certain speech sample as multiethnolectal is lower for the adults, probably because as 'outsiders' - they are less familiar with these ways of speaking than are the adolescent raters (the 'insiders'). Another explanation for this difference in rating between the two groups could be that the 'insiders' do no longer perceive certain features as multiethnolectal because they have already been adopted - via linguistic accommodation - by adolescents lacking a multicultural background.

\section{GENERAL DISCUSSION}

\subsection{Labeling multiethnolectal Zurich German}

The results of the labeling experiment (Exp. 1) showed a considerable variety of labels that are attributed to multiethnolectal Zurich German. It appears that Jugodeutsch and Balkanslang are still widely used. However, we believe that one cannot adopt the frequency of a certain label as the only criterion for the construction of an experiment on sociolinguistic perception. Rather, potential positive and negative connotations of these terms must be taken into account, also considering that in most cases the researchers themselves are perceived by the informants as 'outsiders', which precludes the possibility of an 'appropriation' of derogatory terms (see Bianchi, 2014). For this reason, we ultimately decided to adopt the more neutral term slang, even if it had been mentioned less frequently in the labeling experiment. Nevertheless, we added the second most used label Ausländerdeutsch in brackets and quotation marks, which has the advantage of satisfying the requisite of an emic standpoint, given that some of the adolescents recorded in our corpus do in fact invoke this 
notion in order to distinguish their own way of speaking from what they consider "normal Swiss German".

\subsection{Rating multiethnolectal Zurich German}

The first main finding of our rating experiment (Exp. 2) points to the absence of a clear-cut perceptual boundary between traditional and multiethnolectal speakers of Zurich German, as would have been suggested by the clearly distinct groups mentioned in previous studies on European multiethnolects. Instead, the scores of the rating scale depict a continuum of rating which suggests that adolescents perceive the speech of their peers in many fine-graded shades ranging from rather traditional towards more multiethnolectal ways of speaking Zurich German.

This continuum, which clearly emerges from the results of the rating experiment, reminds of Svendsen's introductory remarks to the edited volume Language, Youth and Identity in the 21st Century (Nortier \& Svendsen, 2015): "the book cuts across traditional binary dichotomies such as 'minority'/"majority' and 'us'/'them' [...]" (Svendsen, 2015 , p. 13). Thus, a perspective on multiethnolectal speech as continuous variable seems to be in line with current research trends in this field.

However, the idea of a perceptual continuum itself is not new in the field of sociophonetics. For instance, Pustka (2007, p. 219-242) found similar continua in the sociolinguistic perception of three regional accents of French, i.e., Aveyron (southern France), Guadeloupe, and Paris. Speakers from these three regions were rated by 218 listeners (mostly French University students) on two scales ranging from $0-100 \%$. Percentages of perceived regionality for the speakers from Aveyron and Guadeloupe were distributed in a continuous manner; moreover, perceived regionality showed clear correlations with sociophonetic variables such as the occurrence of final schwa or nasal consonants in coda position (for similar correlations in multiethnolectal Zurich German see 4.3.).

The second main finding of our study concerns the general ability of lay people to categorize the speech of unknown persons in terms of sociolinguistic perception. Our research project is conducted within a sociophonetic framework which attributes a crucial role to the sociolinguistic perception of linguistic variables. Obviously, this line of research builds on the work of the forerunners in the field of perceptual dialectology (e.g., Preston, 1999); as is well-known, this approach has been extended from the lay categorization of dialects and/or regional varieties to the perception of sociolects as well (see, e.g., Anders, 2010, p. 68). Nevertheless, also this broader perspective of 'integrated perceptual sociolinguistics ${ }^{5}$ still shares the basic assumption that awareness for certain features of a variety

\footnotetext{
Such a broader perspective is also reflected in yet another term which has been proposed in the German-speaking world for the study of sociolinguistic perception, i.e., "perceptual variationist linguistics" (Perzeptive Varietätenlinguistik; see Koppensteiner \& Lenz, 2020; Krefeld \& Pustka, 2010).
}

is "present in everyone and does not require any special training in linguistics [...]" (Sullivan, 2006, pp. 2-3).

The results of our rating experiment basically confirm this statement, but the very similar ratings of adolescents and adults raises some doubts about the dichotomy emic vs. etic: is it really appropriate to conceive of the adults as of 'outsiders', or can they be considered, at least to a certain extent, as 'insiders' as well, given that they belong to the larger community of Zurich German speakers? We leave this question open for further research.

\subsection{From perception to production}

Given the described continuum between the two poles of the 7-point Likert scale, it seems worthwhile correlating individual values of the rating scores with the means of the acoustic measurements obtained for the sociophonetic variables mentioned above (see 1.3.). Thus, the proportion of voicing of lenis plosives or the duration of word-initial fricatives and approximants can be correlated with mean rating scores. Alternatively, two categorical groups could be created with a limited number of speakers whose speech samples were rated highest and lowest in the perception experiment (and who are thus located at the two poles of the continuum). However, such a procedure would lead to the exclusion of the adolescent speakers between these two groups at the risk of reflecting the degree of linguistic variation inaccurately.

Correlations of the rating scores obtained from this categorization experiment and some of the sociophonetic variables mentioned above have already proven to be quite illuminating. On the segmental level, fricative duration in word-initial position correlates significantly with mean rating score (Morand et al., 2019b). On the suprasegmental level, we found significant correlations between mean rating scores and vowel variability measurements, in particular the Normalized Pairwise Variability Index nPVI (Grabe \& Low, 2002) as well as syllable rate (Morand et al., 2020). The use of less vowel reduction in unstressed syllables in multiethnolectal Zurich German leads to the impression of a 'staccato' rhythm of this variety. These promising results will therefore be investigated in more depth within our future research.

\section{CONCLUDING REMARKS}

To sum up, the results of the rating experiment (Exp. 2) show that the sociolinguistic perception of adolescent speech yields a continuum ranging from traditional Zurich German to multiethnolectal Zurich German. Such a continuum is perceived by adolescent raters ('insiders', emic perspective), but there is also a strong correlation of these ratings with the adult raters ('outsiders', etic perspective).

The results of the rating experiment have methodological as well as theoretical implications. We conclude that the perception of multiethnolectal speech should be represented in terms of a continuum rather than in terms of two or more distinct groups (as done in some of the previous research on this topic). 
For the time being, it is not clear which (phonetic) features were most salient to the raters and thus taken as indicators for their decisions. However, our preliminary analyses of both segmental and suprasegmental features have yielded promising results in terms of correlations with the continuum of sociolinguistic perception (see 4.3.). We are currently planning further perception experiments, for example with manipulated or resynthesized stimuli, in order to discover how salient certain acoustic features are in contrast to others in the perception and rating of speech samples. Ultimately, this will allow to predict the weight with which different phonetic features contribute to the perception of multiethnolectal Zurich German.

\section{ACKNOWLEDGMENTS}

This research was supported by the Swiss National Science foundation (Grant No. 165798). We would like to thank all the speakers and raters as well as their teachers for the participation in this study. Furthermore, we would also like to thank the educational board of the city of Zurich as well as the ethic committee of the University of Zurich for granting our applications. Finally, we are indebted with two anonymous reviewers for insightful comments that helped improve our manuscript; needless to say, we alone are responsible for any shortcomings that might remain in this study.

\section{REFERENCES}

Ammon, U. (2003). Dialektschwund, Dialekt-StandardKontinuum, Diglossie: Drei Typen des Verhältnisses Dialekt - Standardvarietät im deutschen Sprachgebiet. In J. K. Androutsopoulos, \& E. Ziegler (Eds.), "Standardfragen": Soziolinguistische Perspektiven auf Sprachgeschichte, Sprachkontakt und Sprachvariation (pp. 163-171). Peter Lang.

Anders, C. A. (2010). Die wahrnehmungsdialektologische Rekodierung von laienlinguistischem Alltagswissen. In C. A. Anders, M. Hundt, \& A. Lasch (Eds.), Perceptual Dialectology: Neue Wege der Dialektologie (pp. 67-87). De Gruyter.

Androutsopoulos, J. (2001). Ultra korregd Alder: Zur medialen Stilisierung und Popularisierung von 'Türkendeutsch'. Deutsche Sprache 4, 321-339.

Appel, R. (1999). Straattaal: De mengtaal van jongeren in Amsterdam. Toegepaste Taalwetenschap in Artikelen 62(2), $39-57$.

Auer, P. (2003). 'Türkenslang': Ein jugendsprachlicher Ethnolekt des Deutschen und seine Transformationen. In A. Häcki Buhofer (Ed.), Spracherwerb und Lebensalter (pp. 255-264). Francke.

Auer, P., \& Røyneland, U. (2020). Modelling acquisition and use of dialectal, standard and multiethnolectal features in migratory contexts across Europe. Journal of Multilingual and Multicultural Development, https://doi.org/10.1080/014 34632.2020.1730385

Berry, J. W. (1999). Emics and etics: A symbiotic conception. Culture \& psychology 5(2), 165-171.

Bodén, P. (2010). Pronunciation in Swedish multiethnolect. In P. Quist, \& B. A. Svendsen (Eds.), Multilingual urban Scandinavia: New linguistic practices (pp. 65-78). Multilingual Matters.

Bruno, M. (2019). Morphosyntaktische Merkmale von multiethnolektalem Zürichdeutsch. University of Zurich MA thesis.

Cheshire, J., \& Fox, S. (2016). From sociolinguistic research to English language teaching. In K. P. Corrigan, \& A. Mearns
(Eds.), Creating and digitizing language corpora (2nd ed.) (pp. 265-290). Palgrave Macmillan.

Cheshire, J., Kerswill, P., Fox S., \& Torgersen, E. (2011). Contact, the feature pool and the speech community: The emergence of Multicultural London English. Journal of Sociolinguistics 15(2), 151-196.

Chiari, B., \& Groß, G. P. (Eds.) (2009). Am Rande Europas? Der Balkan - Raum und Bevölkerung als Wirkungsfelder militärischer Gewalt. De Gruyter.

Clyne, M. (2000). Lingua Franca and ethnolects in Europe and beyond. Sociolinguistica 14, 83-89.

Dieth, E. (1938/1986). Schwyzertütschi Dialäktschrift. DiethSchreibung (2nd ed. by C. Schmid-Cadalbert). Sauerländer.

Dieth, E. (1950). Vademekum der Phonetik: Phonetische Grundlagen für das wissenschaftliche und praktische Studium der Sprachen. Francke.

Dirim, İ., \& Auer, P. (2004). Türkisch sprechen nicht nur die Türken: Über die Unschärfebezeichnung zwischen Sprache und Ethnie in Deutschland. De Gruyter.

Eckert, P., \& McConnell-Ginet, S. (1992). Communities of practice: Where language, gender, and power all live. In K. Hall, M. Bucholtz, \& B. Moonwomon (Eds.), Locating power (pp. 89-99). Berkeley Women and Language Group.

Fagyal, Z., \& Stewart, C. M. (2011). Prosodic style-shifting in preadolescent peer-group interactions in a working-class suburb of Paris. In F. Kern, \& M. Selting (Eds.), Ethnic styles of speaking in European metropolitan areas (pp. 75-99). John Benjamins.

Ferguson, C. (1959). Diglossia. Word 15(2), 325-340.

Fishman, J. (1967). Bilingualism with and without diglossia; diglossia with and without bilingualism. Journal of Social Issues 23(2), 29-38.

Fleischer, J., \& Schmid, S. (2006). Zurich German. Journal of the International Phonetic Association 36(2), 243-253.

Fox, S. (2015). The new Cockney: New ethnicities and adolescent speech in the traditional East End of London. Palgrave Macmillan.

Fox, S., Khan, A., \& Torgersen, E. (2011). The emergence and diffusion of Multicultural English. In F. Kern, \& M. Selting (Eds.), Ethnic styles of speaking in European metropolitan areas (pp. 19-44). John Benjamins.

Freywald, U., Mayr, K., Ozçelik, T., \& Wiese, H. (2011). Kiezdeutsch as a multiethnolect. In F. Kern, \& M. Selting (Eds.), Ethnic styles of speaking in European metropolitan areas (pp. 45-73). John Benjamins.

Füglein, R. (2000). Kanak Sprak: Eine ethnolinguistische Untersuchung eines Sprachphänomens im Deutschen. University of Bamberg Diploma thesis.

Goodglass, H., \& Kaplan, E. (1983). Boston Diagnostic Aphasia Examination (BDAE). Distributed by Psychological Assessment Resources, Odessa, FL.

Gorlée, D. L, \& Anderson, M. (2011). Kenneth L. Pike's semiotic work: Arousing, disputing, and persuading languageand-culture. The American Journal of Semiotics 27(1/4), 243-255.

Grabe, E., \& Low, E. L. (2002). Durational variability in speech and the rhythm class hypothesis. Laboratory Phonology 7 , 515-546.

Grondelaers, S., \& van Gent, P. (2019). How 'deep' is dynamism? Revisiting the evaluation of Moroccan-flavored Netherlandic Dutch. Linguistics Vanguard 5(1), 1-11.

Hayden, R. M. (2013). From Yugoslavia to the Western Balkans: Studies of a European disunion, 1991-2011. Brill.

Häberli, A., \& Wollensack, J. (2006). Code-switching. Zurich University of the Arts MA thesis.

Hägi, S., \& Scharloth, J. (2005). Ist Standarddeutsch für Deutschschweizer eine Fremdsprache? Untersuchungen zu einem Topos des sprachreflexiven Diskurses. Linguistik online 24(3), 19-47.

Hinskens, F. (2011). Emerging Moroccan and Turkish varieties in Dutch. In F. Kern, \& M. Selting (Eds.), Ethnic styles of speaking in European metropolitan areas (pp. 101-129). John Benjamins.

Huber, M. (2000). Gebrochenes Ausländerdeutsch als moderner Sprechstil. Sprachspiegel 56(2), 62-64.

Kern, F., \& Selting, M. (Eds.) (2011). Ethnic styles of speaking in European metropolitan areas. John Benjamins. 
Kerswill, P., Cheshire, J., Fox, S., \& Torgersen, E. (2007). Linguistic innovators: The English of adolescents in London. Final report submitted to the ESRC.

Koppensteiner, W., \& Lenz, A. (2020). Tracing a standard language in Austria using microvariations of Verbal and Matched Guise Technique. Linguistik online 102(2), 47-48.

Kotsinas, U.-B. (1988). Immigrant children's Swedish: A new variety? Journal of Multilingual \& Multicultural Development 9(1-2), 129-140.

Krefeld, T. (2004). Einführung in die Migrationslinguistik. Gunter Narr.

Krefeld, T. \& Pustka, E. (2010). Für eine perzeptive Varietätenlinguistik. In T. Krefeld, \& E. Pustka (Eds.), Perzeptive Varietätenlinguistik (pp. 101-129). Peter Lang.

Lehtonen, H. (2011). Developing multiethnic youth language in Helsinki. In F. Kern, \& M. Selting (Eds.), Ethnic styles of speaking in European metropolitan areas (pp. 291-318). John Benjamins.

Man in Helvetica (2010). Ausländerdeutsch. http://maninhelvetica.blogspot.com/2010/09/deutsch-fur-anfanger.html

Marzo, S., \& Ceuleers, E. (2011). The use of Citétaal among adolescents in Limburg: The role of space appropriation in language variation and change. Journal of Multilingual and Multicultural Development 32(5), 451-464.

Montefiori, N. (2017). Präpupertärer Zweitspracherwerb im Deutschschweizer Kontext University of Fribourg $\mathrm{PhD}$ thesis

Morand, M.-A., Bruno, M., Julmi, N., Schwab, S., \& Schmid, S. (2019a). The voicing of lenis plosives in Zurich German: a sociophonetic marker of (multi-)ethnolectal speech. Proceedings of the 19th International Congress of Phonetic Sciences. Melbourne. https://icphs2019.org/ icphs2019-fullpapers/pdf/full-paper_707.pdf

Morand, M-A., Bruno, M., Julmi, N., Schwab, S. \& Schmid, S. (2019b). Duration of word-initial fricatives in Zurich German: A sociophonetic marker of (multi-)ethnolectal speech. Talk at Phonetik und Phonologie 15, Düsseldorf, 26 September.

Morand, M.-A., Bruno, M., Julmi, N., Schwab, S., \& Schmid, S. (2020). Speech rhythm in multiethnolectal Zurich German. Proceedings of the 10th International Conference on Speech Prosody. Tokyo (virtual). https://doi.org/10.21437/ speechprosody. $2020-116$

Morand, M.-A., Schwab, S., \& Schmid, S. (accepted). Standarddeutsche Interferenzen im Dialektwortschatz Schweizer Jugendlicher: Lexikalische und lautliche Entlehnungen. Bulletin Suisse de Linguistique Appliquée (Vals-Asla).

Nortier, J., \& Dorleijn, M. (2013). Multi-ethnolects: Kebabnorsk, Perkerdansk, Verlan, Kanakensprache, Straattaal, etc. In P. Bakker, \& Y. Matras (Eds.), Contact languages: A comprehensive guide (pp. 229-271). De Gruyter Mouton.

Nortier, J., \& Svendsen, B. A. (Eds.) (2015). Language, youth and identity in the $21^{s t}$ century: Linguistic practices across urban spaces. Cambridge University Press.

Opsahl, T., \& Røyneland, U. (2016). Reality rhymes: Recognition of rap in multicultural Norway. Linguistics and Education 36, 45-54.

Pike, K. (1967). Etic and emic standpoints for the description of behavior. In K. L. Pike (Ed.), Language in relation to a unified theory of the structure of human behavior (pp. 37-72). Mouton \& Co.

Preston, D. R. (1999). Handbook of perceptual dialectology. John Benjamins.
Pustka, E. (2007). Phonologie et varietés en contact. Ayeronnais et Guadeloupéens à Paris. Gunter Narr.

Quist, P. (2010). The sociolinguistic study of youth and multilingual practices in Denmark. In P. Quist, \& B. A. Svendsen (Eds.), Multilingual urban Scandinavia: New linguistic practices (pp. 6-11). Multilingual Matters.

Quist, P., \& Svendsen, B. A. (Eds.) (2010). Multilingual urban Scandinavia: New linguistic practices. De Gruyter.

Rash, F. (1998). The German language in Switzerland: multilingualism, diglossia and variation. Peter Lang.

Riegelnig, J. (2012). Wie spricht Zürich? Stadt Zürich. https:// www.stadt-zuerich.ch/prd/de/index/statistik/publikationen-angebote/publikationen/webartikel/2012-09-06_ Wie-spricht-Zuerich.html

Schmid, S. (2012). Segmental features of Swiss German ethnolects. In S. Calamai, C. Celata, \& L. Ciucci (Eds.), Sociophonetics, at the crossroads of speech variation, processing and communication (pp. 69-72). Scuola Normale Superiore.

Schmid, S. (2017). Differenzierungsprozesse im Sprachgebrauch von Jugendlichen in der Deutschschweiz: zur sozialen Interpretation von ethnolektalen Sprechweisen in Schweizer Medien. Bulletin Suisse de Linguistique Appliquée (Vals-Asla) Special Issue(1), 105-116.

Schmid, S. (2020). Swiss German dialects spoken by second-generation immigrants: Bilingual speech and dialect transformation. Journal of Multilingual and Multicultural development, https:// doi.org/10.1080/01434632.2020.1730386

Schmutz, C. (2013). Balkanslang: Die Sprache geht nicht unter. SRF Literatur. https://www.srf.ch/kultur/literatur/ balkanslang-die-sprache-geht-nicht-unter

Siegel, V. (2018). Multiethnolektale Syntax: Artikel, Präpositionen und Pronomen in der Jugendsprache. Universitätsverlag Winter.

Stadt Zürich (2018). Bevölkerung nach Nationalität, Stadtkreis und Stadtquartier, seit 1993. https://www.stadt-zuerich. $\mathrm{ch} /$ content/dam/stzh/prd/Deutsch/Statistik/Themen/ Bevoelkerung/BEV336T3360_Bevoelkerung_nachNationalitaet-Stadtkreis-Stadtquartier.xlsx

Stadt Zürich (2019). Ausländische Bevölkerung nach Nationalität und Aufenthaltsart, seit 1993. https://www. stadt-zuerich.ch/content/dam/stzh/prd/Deutsch/Statistik/ Themen/Bevoelkerung/BEV337T3370_AuslaendischeBevoelkerung_nach-Nationalitaet-Aufenthaltsart.xlsx

Sullivan, C. (2006). Towards an integrated perceptual sociolinguistics. Haverford College Senior thesis.

Svendsen, B. A. (2015). Language, youth and identity in the $21^{\text {st }}$ century: Content and continuations. In J. Nortier, \& B. A. Svendsen (Eds.), Language, youth and identity in the $21^{\text {st }}$ century: Linguistic practices across urban spaces (pp. 3-23). Cambridge University Press

Tissot, F., Schmid, S., \& Galliker, E. (2011). Ethnolektales Schweizerdeutsch. In E. Glaser, J. E. Schmidt, \& N. Frey (Eds.), Dynamik des Dialekts: Wandel und Variation (pp. 319-344). Steiner Verlag

Torgersen, E., \& Szakay, A. (2012). An investigation of speech rhythm in London English. Lingua 122, 822-840.

Wiese, H. (2006). "Ich mach dich Messer": Grammatische Produktivität in Kiez-Sprache ("Kanak Sprak"). Linguistische Berichte 207, 245-273.

Woker, M. (2008, December 12). Der Balkan und seine Grenzen. Neue Zürcher Zeitung, https://www.nzz.ch 